\title{
Roots, tendrils, seeds and shoots: A case study of Parkallen's community garden, a permaculture project
}

\author{
Marlene Wurfel* \\ MacEwan University, Canada
}

\begin{abstract}
The first growing season of Edmonton's Parkallen Community Garden began in Spring 2012. We transformed an unused strip of lawn bordering our hockey rink into a loamy, thriving "edible food forest" of corn, beans, squash, kale, tomatoes, carrots, potatoes, apple trees, and mammoth sunflowers. It is unlike most community gardens in that individual plots are not tended by individual gardeners; rather, the PCG is tended communally, by the community. The garden is open and accessible to the community, always, and all are welcome there, from the toddler whose only contribution is to chomp on a snowpea and water a dandelion, to the senior who wants to plant a tree in his community that he knows will outlive him. Hundreds of Parkallen residents have planted something, admired something, or munched on something there. In its first year Parkallen's garden won The City of Edmonton's top community gardening award from Communities in Bloom. This article is a case study of the Parkallen Community Garden. Through the lenses and observations of the author, it details how Parkallen's permaculture design came, literally, to fruition and how permaculture has been interpreted and how it informs our garden and our gardening community.
\end{abstract}




\section{The Seeds}

Passersby of the Parkallen Community Garden have remarked to me that it seemed to spring up out of nowhere. For years they would walk or drive down $65^{\text {th }}$ street and find nothing at all noteworthy about the stretch of grass between the hockey rink and the sidewalk. In a city that boasts over 4,500 hectares of maintained parkland and urban green spaces (City of Edmonton), an area that could fit more than 23 of New York City's Central Park within it (City of New York, 2013), the small length of lawn that would become the Parkallen Community Garden couldn't be less remarkable. Then, in the summer of 2012, mammoth sunflowers sprouted upwards through the fresh, loamy soil and began to rapidly tower their massive, heavy heads upwards. They are a showy flower and they weren't there before. Passersby did find that remarkable. Stepping down the garden path, visitor's would find themselves in an urban "food forest" with herbs, tomatoes, corn, beans, carrots, beets, turnips, apple trees, nut and berry bushes, strawberries, kale and pumpkin plants growing in lush beds and borders where, since 1954, there was just neatly mown, ignorable grass (City of Edmonton, 2009).

"Ka-boing!" is the word several observers used to describe the appearance of the Parkallen Community Garden to me in its first growing season.

Parkallen is a mature Edmonton neighbourhood originally designed by city planner Noel Dant, post-WWII, as his ideal vision of a suburban community (City of Edmonton, 2009). Old elms and ash trees canopy the wide streets. Because of Dant's planning, traffic bypasses Parkallen if it isn't local, or, if it is local, traffic slows down. Dant designed Parkallen using the "English Garden Model," meaning that all the homes in the community surround a central greenspace at the heart of the community in which the community hall, school, playground, and, now, the Parkallen Communty Garden are seated (City of Edmonton, 2009). Since the 1950's, the "green" of that central greenspace has been defined by the grass and shade trees planted and maintained by the City of Edmonton, as well as some annual and flower-beds maintained by volunteers. There's been plenty of green in Parkallen's "English Garden," but none of it has been edible. In today's metropolitan Edmonton, Parkallen is no longer a suburban, but rather an urban community. In the most recent Parkallen Community Development Plan by the City of Edmonton (circa 1994, republished in 2013), the vision statements of Parkallen's urban planners insist on "respecting, enhancing, and strengthening Parkallen's urban lifestyle” by promoting walking, cycling and the use of public transit. City planning task forces are committed to preserving "the area's local character, urban lifestyle, and sense of place (City of Edmonton, 2013, p 5., emphasis mine)." During Parkallen's 
shift, over the past six decades, from suburban to urban, the large, public park space has stayed central to community's geography. The emergence of a community food garden in what is now Parkallen's urban greenspace is certainly part of a broader trend 'in foodbased social movements and grass-roots initiatives around the world, from slow food to community gardens (2011, Turner, Henryks \& Pearson, p. 492).

In 2009, Transport Canada and the City of Edmonton showcased an ecotransportation project called Local Motion with Parkallen as the pilot community. Local Motion was "conceived as an opportunity to use a community based approach to encourage the use of ecofriendly modes of transportation (City of Edmonton, 2011)". For one month, in June of 2009, Parkallen residents were asked to use alternative transportation, i.e. alternative to cars. This project had two very significant, to the Parkallen Community Garden, results. Firstly, the community-based volunteers who worked on the municipally and federally-funded project were galvanized together as a group who shared mutual concerns and goals regarding sustainability. They formed a sub-committee of the Parkallen Community League directed by Robert Kirchner, an elected Sustainability Coordinator. 'Parkallen's Local Motion project (2009) brought together a critical mass of residents eager to work together on neighbourhood sustainability initiatives (Kirchner, 2011)." When the Local Motion project wrapped up, interest in working towards sustainability-related goals did not. Creating a community garden in Parkallen became the focus of that group, and so the figurative seeds of the PCG were planted. Through a community-wide survey initiated by the Park Redevelopment Committee (a sub-committee of the Parkallen Community League) wider-spread interest in creating a community garden was gauged in the community atlarge. Secondly, the Local Motion project garnered the Parkallen Community League a "Green Award" which the Community League earmarked for the creation of a community vegetable garden (Edmonton Federation of Community Leagues, 2010). Thus, the seeds (as in the idea to create a garden) and the seed money (literally, money to buy seeds and other materials) were in place.

Two years later, in the early spring of 2012, when the ground was still snow-crusted and frozen, I picked out a pack of mammoth sunflower seeds from the Sustainable Food Edmonton Seed Bank at their annual potluck event and brought them home in my pocket. After the ground had thawed, at a community garden work bee, a neighborhood mom asked me what she and her young daughters might do to help. I pulled the seeds out of my pocket and suggested a line of them at the back edge of the garden. By summer, the sunflowers were much taller than the daughters or their mother. They 
stood tall in the garden, turning the heads of passersby. Before those sunflower seeds could sprout, however, we needed to build soil where there was just grass.

\section{The Soil}

The community gardening group led by Robert Kirchner called themselves "The Parkallen Diggers" in tribute to the egalitarian, $17^{\text {th }}$ century movement which practiced community gardening as a form of nonviolent protest to the enclosure of common lands (Kirchner, 2011). Their vision was a permaculture garden and towards that end they hired a local permaculturist, Dustin Bajer, to design an edible food forest in Parkallen's central park.

Permaculture is a practice and a model for designing spaces, like gardens, that provide for human needs. Permaculture strives to create and/or enable ecological, stable and productive systems that give as much or more than they take from the earth, or from the people who tend them. The ideal permaculture garden is self-sustaining, requiring no work from the gardeners themselves, yet produces maximal yields of food (Praetorius, 2006, p. 6). The ideal food forest contains only productive, beneficial plants but always instills a sense of well-being in visitors by virtue of its beautiful and intentional design. Think of walking into a garden with a basket and reaching up towards a low-hanging bough of apples with one hand, and down to pick an heirloom pumpkin with the other.

The permaculture method was pioneered by Australians Bill Mollison and David Holmgren during the 1970s. It combines the words "permanent", "agriculture," and "culture." The environmental and the social dimensions of greenspaces are essential considerations of the permaculturist (2011, Roth.)

I first became involved in the PCG when designer and educator Dustin Bajer led a permaculture info session hosted by the Parkallen Diggers at the Parkallen Community Hall, advertised in the community newsletter as free and open to all interested potential gardeners. I was interested. The workshop was meant to perform double-duty (how permaculture!) by providing information and building community at the same time. At that workshop, I learned some of the principles and practices of permaculture including the "no-till" or "no-dig" approach to soil that the Parkallen Diggers (irony noted) espouse.

A mainstream idea of soil is that it is a commodity that is purchased from a garden

center by the truckload and moved to where it is needed. This is not inaccurate - soil can 
be purchased by the truckload - but this is not the only way to construe soil. Soil can be built. Soil, if given the right conditions, builds itself. Given the right conditions, soil builds itself so brilliantly it has to be seen to be believed. Building, instead of buying soil, is one key difference between the PCG and most community gardens. It is the reason why the PCG's construction budget was much lower than average and also one of the reasons the PCG seemed, to onlookers, to go "Kaboing!" At no point during the construction of the PCG was the ground broken and cultivated by machines nor was a truckload of soil purchased and delivered, a budget-item that comprises most of many garden's construction budgets. Instead, soil was created by the no-till method of sheetmulching or lasagna gardening. To create soil using the lasagna gardening method, the Diggers arranged layers of mulch over top of the pre-existing grass.

In one weekend, during the summer of 2011, after gathering the readily available, inexpensive (or free!) and locally-sourced materials - cardboard, straw, and compost needed for the individual mulch layers, the Diggers set the sheet mulch in place. After that original investment of physical work, the cardboard sheet-mulch killed the grass underneath entirely and composted the pre-existing and added organic matter over the fall and winter, so that by the Spring of 2012, without any effort by people or machines, wonderfully fertile and loamy soil beds lay ready for planting. The local girls planted their sunflowers without even a trowel - they simply walked along the garden's edge and poked the seeds into the loam with their little fingers. No-till farming is described in a University of Edinburgh critical assessment as "a superior form of agriculture in virtually all respects (2004, Trewavas). Researcher Anthony Trewavas concludes his scrutiny of the dogmas and practical realities of conventional, holistic and organic farming methods by insisting that no-till farming "merits much more attention than it currently gets (author's emphasis)".

Well-wishers offer to rototill the Parkallen Community Garden each spring but their kind offers are politely declined. The no-till approach to soil deems turning the soil to be too high-cost of an activity. Tilling costs gardeners the effort of turning the soil, it churns and effectively plants weed seeds that need to be pulled later in the season, and it depletes soil health. Rototilling lessens the soil's ability to hold water and decreases the populations of beneficial insects that prey on pests (Trewavas, 2004, pp. 774-775). Understanding soil as a living organism with a sort of "intelligence" to its layers that should be disturbed as little as possible is at once a core philosophy and a core practice of permaculture. 
The no-till approach at the PCG does not mean that the Diggers have never, and never will wield a shovel. If an apple tree needs to be planted, we, of course, dig a hole. Before the soil was built using the lasagna gardening method, the designer directed (and helped!) the gardeners to dig a swale the length of the north sloped-side of the garden. The gravel-filled swale serves as a rain-catchment to hold water in the garden during heavy rains and melts. Water - where it comes from and where it goes - is carefully studied by the permaculturist, much like the direction of the sun is observed and considered, and such observations are essential to the design process.

\section{The Design}

Careful, intentional design is a core value of permaculture (Shein \& Thompson, 2009. p.29)". The permaculturist deploys two special techniques for analyzing and designing a garden: sectors and zones. Thinking through the unique sectors (e.g. public access, direction of the sun, direction of the wind, wildlife, desirable and undesirable views) of any potential garden allows the designer to understand "the garden's relationship to the surrounding environment (p.66)". Thinking through the zones (e.g. the self and home (zone 0), intensely cultivated space (zone 1), unmanaged nature (zone 5 ), etc.) encourages the permaculturist to assess the gardeners' relationship(s) to the garden and how much work will be required to tend the garden once it is in place.

Consider the example of access to water: the PCG garden is designed to be as "selfwatering" as possible. Swales and rain-barrels to catch water, which would otherwise run off towards street-gutters or be absorbed into the surrounding lawn, have been installed as a primary consideration. Nevertheless, the PCG designer knew we'd need access to water when doing the original sheet mulching, during occasional dry-spells and to waterin certain projects, like planting fruit trees. The area sloping away from the hockey rink had several advantages as a location: 1) it wasn't been used by anyone as its slope towards a roadway, and proximity to a large playground and soccer field made it unattractive as a play-space 2) it had access to water (the community league's hosesystem used to flood the rink every winter) and 3) because of its location and slope it could, using swales, catch and store the run-off every spring as the snow and rink-ice melted. Integrating water-catchment and access into the original garden design is a very different process from choosing a place to build a garden and then figuring out how to get water to it once it is built, planted and the lettuce is wilting. The careful analysis of the water sector considered water access in the short-term and for the long-term, by thinking through how the PCG could conserve water as a whole system. While considering where and how you will water is a basic consideration of any competent 
garden designer, the special focus in permaculture is not on water as a separate component, but as an integrated element that must provide benefits to the whole system.

\section{Sustainable People}

Many view gardening as an activity for people who love physical work. The value for and enjoyment of gardening as a physical activity is considerable in some age groups (i.e. adults) but not all: children and college students value gardening not as a physical activity but as an emotionally valuable activity. (Mecham \& Joiner, 2012 p. 231) In Mecham \& Joiner's 2012 study of College Students' Gardening Experiences, entitled "Even If We Never Ate A Single Bite Of It; It would Still Be Worth It," college-aged students are reported to value community gardening for the knowledge and skills they gain and plan to use in living a more sustainable lifestyle in the future.

As a volunteer in the PCG, very little of the "work" I do is physical. I engage mostly in planning, documenting, outreach, communications, reporting, and, when in the garden, coaching, teaching, and leading. Working smarter and not harder is a great goal for any gardening group because the real benefits of a garden extend beyond physical activity to include social, psychological, and even economic gains (Mecham \& Joiner, p. 231). If I was in it for the workout, I'd go to the gym. If I was in it for the vegetables, I'd go to the farmer's market. My personal reasons for devoting much of my time and energy as a community garden director and volunteer are to share my knowledge and skills, to increase my knowledge and skills, to feel connected to my community, to provide a healthy activity and experience for my children and my neighbour's children, to ensure those same urban children aren't disconnected, but connected to where at least some of their food comes from, to make sustainable food a visible agenda in my community, to meet and enjoy like-minded people, and to create a green sanctuary that I can enjoy. The fresh carrots are simply a fringe benefit.

The original group of sustainability-minded people who coalesced in Parkallen to start the community garden are no longer active in the PCG. I couldn't accurately calculate how many hours they spent in meeting, grant-application, planning, consulting, form-completing, and report-writing in order to navigate the various requirements and agreements between the Parkallen Diggers, The Parkallen Community League, and the City of Edmonton, so that the PCG could be constructed on that strip of grass south of the hockey rink. I do know, however, that the garden did not actually go "ka-boing," and that a bureaucratic permission-seeking process through the City of Edmonton had to be navigated. I also know that somewhere, between 2009 when the idea was germinated and 2011 when the first seed was planted, the original group had metamorphosed into a new 
group. One way of looking at this is that the PCG has had a burn-out rate of $100 \%$ since its inception just three years ago.

Can a gardening group use the same permaculture principles and values that catch and conserve water to create a stable and sustainable volunteer-base? Can intentional and careful design of a gardening group produce a community that, like an edible-food forest, is complex, self-sustaining, and nearly effortlessly productive?

\section{The Forest}

A lawn is a monoculture. A field of corn is a monoculture. One blight or storm can destroy or flatten a monoculture. A forest, on the other hand, is a complex system. There is a canopy layer, a shrub layer, a soil layer, and a rhizome layer. If it's a poor year for something in a forest, say the hazelnuts, something else is likely to have a great year, maybe the oyster mushrooms. Permaculture values the forest model for its productivity, diversity, and stability (Shein \& Thompson, 2009, p. 46).

To encourage the strength and complexity of a garden, the permaculture layers fruit trees, fruit and nut-bearing shrubs, vegetables, herbs, and low-spreading vines such as pumpkins. You don't need a background in permaculture to understand what "an edible food forest" is. Standing in the PCG and observing a tall corn stalk with runner-beans climbing up it and a blue hubbard-squash vine spreading out underneath it is a fairly complete lesson in permaculture. There are not neat rows where one might expect neat rows. Rather, plants grow in guilds, strata and poetries. The intention is not to mimic a farm planted with the end-goal of being efficient to plow and machine-harvest, but to mimic a forest that has naturally evolved towards complexity, diversity and stability.

How can we mimic the forest model within our community of gardeners? How can we build a stable forest of gardeners?

Most permaculture books and courses focus on tending for plants (2011, Roth). Literature on how to encourage a social permaculture is much less abundant than that on how to nurture a vegetable permaculture.

Looking to idealized nature for design inspiration is certainly not a new idea (Clavin, 2011, p. 947). "Since ancient times, designers have looked to nature and ecological systems for solutions to their common problems" seeing nature as "a perfect model to follow" (ibid.). Is nature, in fact, a good role model? Does modeling upon natural systems yield positive results? 
Leeds Metropolitan University's Alma Calvin's research in "Realising ecologogical sustainability in community gardens," demonstrates that community gardeners who follow natural and sustainable models of gardening, such as permaculture, experience the greatest levels of well-being and satisfaction from their gardening experiences (p. 951, see Tables 1 \& 2). Calvin reports a correlation between gardeners working within a nonrigid design system that is open and responsive to multiple feedback loops, the gardener's sense of empowerment to make decisions in the garden at the micro-level, and the gardener's enhanced sense of wellbeing from gardening (p. 950). Says Calvin:

The wellbeing capabilities and functionings associated with agency are facilitated by an everfluctuating environment, continuously offering the user new opportunities in a safe space to express oneself, restore and learn. Although ever changing, the sites are kept in check by ecological site processes and a non-rigid design maintained by a site coordinator/gardener - maintaining dynamic balance. It is the combination of agency and dynamic balance which is the essence of realizing ecological sustainability in these community gardens. (p. 952)

My instinct as a director of the PCG is to avoid over-prescriptive rules in the garden. It means less work for me if I don't have to enforce any rules in particular, and moreover, I want to let people respond to the garden on their own terms. I want people to read the PCG, like one reads a story or a blog post, and form a personal, subjective reaction. I want the PCG to invite people to explore their relationships with food and with food production, as well as with the strangers next door. I want it to open dialogue surrounding our relationship with public space and civic space, as well as our relationships with rules themselves.

The same study that demonstrates that community gardeners respond very positively to a sense of agency and the freedom to be self-led, also reveals that community gardeners do not "particularly value opportunities to participate in the more organizational and managerial aspects of site design and development" (p. 954). Calvin also points out that an "ever-changing, non-rigid and user-led approach perhaps does not bode well with the more rigid zoning and planning tools imposed by planning authorities" (p. 956.) Indeed, we feel that the amount of paperwork required of us by City authorities is onerous, especially because our garden does not fit into their standard forms, e.g. "How many individual plots do you have? What is the size of each plot?" Their response is to ask for more and more documentation about our internal processes to the point that those internal processes themselves become threatened by the paperwork burden required to document them. 
My instinct as a CG director is to protect other members of our gardening group from the amount of paperwork required to keep the garden in funds and permissions. This has the effect, however, of keeping me out of the garden since the number of hours I can devote to the PCG each month are finite. It also prevents me from spending my time on community-building which means that if I am approaching burn-out under my current volunteer-load, it's unlikely that I'll have others to rely on, which could be the makings of a vicious, downspiraling cycle. Our core members have been writing Terms of Reference to satisfy grant requirements, instead of tending green-beans and thinning carrots together with our neighbours. This growing season, only our second, has left us feeling like we're in a somewhat fragile place: more a period of stasis than growth.

If we take a lesson from our garden, and from what has worked so far, increasing the number and diversity of our community gardeners should be a top-priority. Tending to whatever creates a sense of well-being among gardeners should be another.

\section{Tendrils and Shoots}

In my experience building the garden hasn't been just about moving dirt around. It has been a much greater task of creating and nurturing networks and relationships. By a somewhat mysterious process to me, it seems that networks and relationships are created and nurtured most effectively, however, by being in the garden moving dirt around. That is where I discovered my neighbour's kid digging organic carrots and potatoes to bring home to his mom while she was fighting for her life undergoing chemotherapy. That is where I gave the single-mom and her daughter up the street permission to pick as much kale as they wanted when they told me they'd been ogling it for months. That is where I met the gardener across the street who started the Edmonton's Grow a Row for the Foodbank campaign. She crossed the street to ask me if I wanted to split a truckload of compost. That is where a woman stopped and hopped off her bike to tell me how much she loved seeing the garden every day and how she took the long way to work just to look at it.

“Take home something to eat," I called after her.

“No! I couldn't! I just love to look at it!” she replied.

Permaculture encourages gardeners to view a garden space as designed for people's use and enjoyment; gardens should not be designed to use people, nor to use up natural resources in a way that is unsustainable. Conserving your effort, your money and the environment are mutual goals in a permaculture garden. 
Before constructing our garden with no individual plots, no fences, and no signs saying what not to do, so many naysayers told us it would never work. 'You'll do so much and get nothing in return because some jerk who didn't lift a finger will raid your garden. You'll see". In fact, the reverse is true. It has been much more difficult to convince people that they deserve to take home some garden produce than to prevent people from taking too much. And while I have done so much work, yes, more than I would have bargained for, it isn't true that I've gotten nothing in return. I've come to the garden for just a few leaves of basil and oregano and, after getting lost in the task of dead-heading edible flowers, left with a feeling of wellness and peace.

\section{Conclusion}

"Our sunflowers are visible from space," one of the PCG's co-directors pointed out to me the other day. We were grudgingly collaborating on an addendum to a report about our garden bylaws, regulations and procedures, when we found ourselves looking down on the garden via Google Earth via my laptop. It's true, and it's surreal: you can see those sunflowers from space.

I am proud to see them beaming back at me. In a way, I made that, I made them happen. But on a fundamental level, I know that I haven't really made the Parkallen Community Garden grow. I've planted things there. I've asked for and received grant funding. I've reached out to my neighbours and asked them to garden with me. But mostly, the multiple points of connection just keep sprawling out from the soil like pumpkin vines, sending tendrils in every direction they can. Our job as gardeners seems to be mostly about looking under leaves to see what's appeared there on any given day. What fascinates and motivates me most of all is all the work the garden does on its own. A girl is handed a seed, she pokes it into the earth, and the rain and the sun and the soil do the lion's share of the work. If you let them, they really do.

* Author: Marlene Wurfel has been teaching Communications at MacEwan University since 2012. She has an M.A. in English from the University of Alberta. She's written professionally for the stage, the page and also for television. Her favourite gardening implement is the Hori Hori knife. She's what you'd call an outdoorsy person. Her research interests include permaculture and systems theory. 


\section{References}

Edmonton Federation of Community Leagues (2010). Green Challenge. http://www.efcl.org/EFCLActivitiesOverview/MemoryLane/GreenChallenge09_ 10/tabid/190/Default.aspx

City of Edmonton, Department of Transportation. (2009). Parkallen Community Local Motion Field Guide. [Brochure]. Retrieved from: http://www.edmonton.ca/transportation/Field Guide to LocalMotion.pdf

City of Edmonton. Stay Inside the Lines: Protecting Edmonton's parks and natural spaces for everyone. [Brochure]. Retrieved from: http://www.edmonton.ca/environmental/documents/PDF/stay inside the lines. pdf

City of Edmonton (2013). Parkallen Community Development Plan. Retrieved from: http://www.edmonton.ca/city government/documents/Parkallen CDP May 201 $\underline{3 . p d f}$

City of New York. Retrieved from: http://www.centralparknyc.org/about/

Clavin, A. (November, 2011). Realising ecological sustainability in community gardens: a capability approach. Local Environment, 16(10), 945-962.

Kirchner, Robert. (2011). About the Parkallen Community Garden. Retrieved from: http://parkallendiggers.org/about/

N. A. Mecham \& L. R. Joiner. (2012). "Even If We Never Ate A Single Bite Of It; It would Still Be Worth It:” College Students' Gardening Experiences. Journal of Ethnographic \& Qualitative Research, 6: 231-242.

Praetorius, Patrick. (2006). Teaching Through Permaculture Experience. Connect, Nov Dec: 6-9.

Shein, C. \& Thompson, J. (2013). The Vegetable Gardener's Guide to Perma-Culture: Creating an edible ecosystem. Portland: Timber Press.

Roth, C. (2011). Permaculture 101. Communities, 153: 10-12.

Trewavas, Anthony. (2004). A critical assessment of organic farming-and-food assertions with particular respect to the UK and the potential environmental benefits of no till agriculture. Elsevier: 23: 757-781.

Turner, Henryks \& Pearson. (2011). Community gardens: sustainability health and inclusion in the city. [Editorial]. Local Environment 16(6): 489-492. 